\title{
Attitudes, Self-confidence, and Independence of Students in Thematic Learning
}

\author{
Syahrial, Asrial", Husni Sabil, Arsil \\ Faculty of Teaching and Education, Universitas Jambi, Indonesia
}

Received November 4, 2019; Revised December 20, 2019; Accepted December 25, 2019

\begin{abstract}
Copyright $\mathrm{O} 2020$ by authors, all rights reserved. Authors agree that this article remains permanently open access under the terms of the Creative Commons Attribution License 4.0 International License
\end{abstract}

\begin{abstract}
Purpose: Affective aspect is one of the aspects that is very calculated at this time. Therefore, this study aims to see whether there is a relationship between attitude and independence and self-confidence of students in the thematic learning of students in primary schools. Method: This type of research is associative quantitative research with correlational design. Where the total number of samples from this study was 130 students with details of 60 male students and 70 female students taken based on purposive sampling techniques. The data were then analyzed with the help of the SPSS 21 application to look for descriptive statistics in the form of mean, min, and max as well as the relationship between attitudes and interests. Findings: From the results of the analysis that has been done, it is found that there is an attitude with independence and good student confidence shown by the dominance of the good category and strengthened by the existence of a relationship between students' attitudes and independence in thematic learning and students' attitudes and confidence in thematic learning.
\end{abstract}

Keywords Attitude, Independence, Confidence, Thematic

\section{Introduction}

One of the standards of education is the affective aspect, therefore the development of the affective aspect is needed because if it has good affective aspects, cognitive and psychomotor will also be good [1]; [2]. One of the basic education in Indonesia is elementary/MI equivalent of six years, which is the foundation or foundation of education. If a child receives an education service in primary school properly and correctly, the students will have a greater chance of success at the next level of education. [3] Said that children who are in the early grades of primary school are children who are in the early age range. This early age period is a short period but is a very important period of one's life. Therefore, at this time all the potential possessed by children needs to be encouraged so that it will develop optimally [4]; [5]; [6]. In elementary schools, there is thematic learning, thematic learning integrated learning that uses themes as a unifying learning activity that combines several subjects at once in one face-to-face meeting, to provide meaningful experiences for students [7]. [8] Thematic learning places more emphasis on the active involvement of students in the learning process so that they can gain hands-on experience and the child is trained to be able to discover a variety of knowledge learned, according to Law No. 20 of 2003 in current education, not only in terms of cognitive but also in terms of affective (attitude).

Attitudes related to the management of emotions that occur during the learning process and play an important role in directing human behavior [9]; [10]. Attitude assessment is assessed indirectly and continuously on all subjects based on positive and negative attitudes during school entry and exit from learning, using observation sheets or questionnaires [11]; [12]. The attitude that students have can also affect the independence and confidence of students.

Confidence is priceless. By having confidence, a person can do anything with the belief that it will succeed, if it fails, one does not necessarily despair, but still has the enthusiasm, remains realistic, and then firmly tries again [13]. As stated by Hakim [14], which is the confidence of each person is one of the souls that determines the success or failure of the person in achieving various goals in life. With a lack of confidence, a sense of inferiority will overwhelm someone in his life, and he will grow into a pessimistic person. As stated by [15] that without the confidence that is firmly planted in the soul of the child (students), pessimism and low self-esteem will be able to master it easily. One aspect of counseling or student that needs to be considered is self-confidence, which is one of the assets in life that must be grown on each student so that 
one day they can become human beings who are able to control various aspects of themselves, with the ability these students will be clearer in setting clear personal goals and objectives, then they will be better able to direct behavior towards success. As stated by Abdul Mu'in [16] that self-confidence is a condition in a person that contains the strengths, abilities, and skills possessed by a person and will create student independence.

Learning independence is an active learning activity, which is driven by the intention or motive to master competency in order to overcome a problem, and is built on the knowledge or competency that is possessed [17]; [18]. Determination of competence as a learning goal, and how to achieve it - both the determination of study time, place of learning, the rhythm of learning, the tempo of learning, ways of learning, and evaluation of learning-are carried out by students themselves. According [19]; [20] states the independence of students in learning is an attitude that leads to awareness to learn on their own without help from others with all the decisions, considerations related to learning activities so that students can be fully responsible for the learning process.

Students who have the independence of learning can be seen from several characteristics that look like behavior or skills or that do not look like thinking patterns and cognitive abilities. According to [21] Independence is usually characterized by several characteristics, including the ability to determine one's own destiny, creativity and initiative, regulate behavior, be responsible, be able to restrain, make their own decisions, and be able to overcome problems without the influence of others. Learning independence is very important for students in an effort to minimize the phenomena of learning that are less independent, such as: not comfortable studying long in class or studying only before the exam, ditching, cheating, passive in the classroom. In addition, efforts to keep students away from the complexity of problems in the community that can directly or indirectly affect the student learning independence [22].

Therefore, the purpose of this study is to look at the relationship between students 'attitudes towards students' independence and self-confidence.

\section{Materials and Methods}

Quantitative research methods with correlational research designs, associative quantitative research are the relationship between two or more variables [23]. Because research is associative research, researchers take correlational research designs. According to [24] "Correlation Design in quantitative research is used to measure the level of association (relationship) between two variables using statistical analysis of correlation procedures".

The sample of students from elementary schools in Batanghari District obtained 130 students with the details of 60 male students and 70 female students using purposive sampling. Purposive sampling is a sampling technique based on researchers' criteria [23]. In this study, the criteria used include schools that have been accredited A and students who learn thematically, they are grade 4 , grade 5 , and grade 6. In this study, this study used three questionnaire instruments, attitude questionnaires adopted and adapted from [25] has 36 valid statements with a reliability of 0.72 , the confidence questionnaire was adapted from [13] with 24 valid statements, and the independence questionnaire was adapted from [26] with 21 valid statements. The type of data in this study uses ordinal data. The questionnaire uses a Likert scale of 5 (five) for positive statements Strongly Disagree has a score of 1 , Disagrees has a score of 2, Natural has a score of 3, Agrees to have a score of 4 and Strongly Agrees 5. For negative statements Strongly Disagrees has a score of 5, Disagree has a score of 4, Natural has a score of 3 Agree has a score of 2 and Strongly Agree has a score of 1.

Data used by the SPSS program to look for descriptive and inferential statistics. For example, shape, median, minimum, maximum and standard deviation [27]. Statistical conclusions can be drawn from mathematical procedures for using probabilities and information about samples to draw conclusions about the populations from which samples might be taken [23]. In this study, there are prerequisite tests and hypothesis tests, and product hypothesis testing using product-moment correlation hypotheses.

Below is a category of attitudes, independence and self-confidence in the questionnaire in thematic learning, including very good, good, enough, not good, and not very good, as in table 1 below:

Table 1. Categories of students' attitudes, independence, and confidence in thematic learning

\begin{tabular}{|c|c|c|c|}
\hline \multirow{2}{*}{ Category } & \multicolumn{3}{|c|}{ Interval } \\
\cline { 2 - 4 } & Attitude & Independence & Self-confidence \\
\hline $\begin{array}{c}\text { Very Not } \\
\text { Good }\end{array}$ & $36.0-64.8$ & $24.0-43.2$ & $21.0-37.8$ \\
\hline Not Good & $64.9-93.6$ & $43.3-62.4$ & $37.9-54.6$ \\
\hline Enough & $93.7-122.4$ & $62.5-81.6$ & $54.7-71.4$ \\
\hline Good & $122.5-151.2$ & $81.7-100.8$ & $71.5-88.2$ \\
\hline Very Good & $151.3-180.0$ & $100.9-120.0$ & $88.3-105.0$ \\
\hline
\end{tabular}

In this study the data collection procedure can be seen in Figure 1 below. 


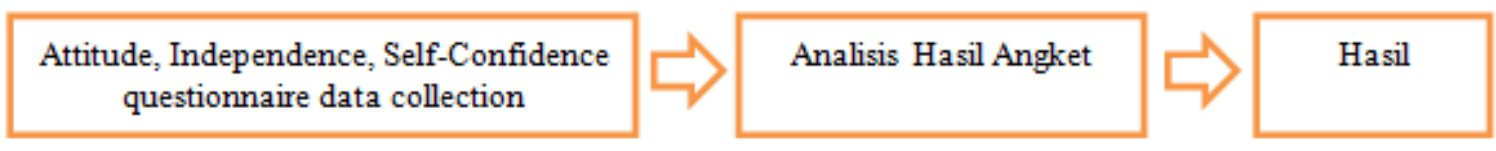

Figure 1. Data Collection

During data collection, the first activity that must be done is to select students based on the categories provided by the researcher, then give a questionnaire of attitude, independence and confidence to students, the questionnaire is then processed using SPSS 21 application data to see descriptive statistics, in the form of, the mean, min, max, percentage and category of students and to see whether there is a relationship between the three variables

\section{Results}

Research findings are explained in this section. The Category, Mean, Min, Max, and Percentage results and correlated the three variables are presented as follows.

Table 2. Attitudes of students in Batanghari elementary school

\begin{tabular}{|c|c|c|c|c|c|c|}
\hline \multicolumn{3}{|c|}{ Classification } & \multirow{2}{*}{ Mean } & \multirow{2}{*}{ Min } & \multirow{2}{*}{ Max } & \multirow{2}{*}{$\%$} \\
\hline Range & Attitude & Total & & & & \\
\hline $36.0-64.8$ & Not very good & 0 & \multirow{5}{*}{135} & \multirow{5}{*}{94} & \multirow{5}{*}{171} & 0.0 \\
\hline $64.9-93.6$ & Not good & 0 & & & & 0.0 \\
\hline $93.7-122.4$ & Enough & 25 & & & & 19.2 \\
\hline $122.5-151.2$ & Good & 76 & & & & 58.5 \\
\hline $151.3-180.0$ & Very good & 29 & & & & 22.3 \\
\hline TOTAL & & 130 & & & & 100 \\
\hline
\end{tabular}

From table 2, which came from 130 respondents from elementary school students in Batanghari, after being processed and the results obtained using the SPSS 21 application program, it was found that students' attitudes in the thematic had a good category of $58.5 \%$ to 76 students from 130 total students, enough at $19.2 \%$ for a total of 25 students out of 130 total students, very good $22.3 \%$ for 29 students out of 130 total students. Of the 130 students having a Mean value of 135 , a Maximum Value of 171, and a Minimum Value of 94.

Table 3. Independence of students in the Batanghari elementary school

\begin{tabular}{|c|c|c|c|c|c|c|}
\hline \multicolumn{3}{|c|}{ Classification } & \multirow{2}{*}{ Mean } & \multirow{2}{*}{ Min } & \multirow{2}{*}{ Max } & \multirow{2}{*}{$\%$} \\
\hline Range & Independence & Total & & & & \\
\hline $24.0-43.2$ & Not very good & 0 & \multirow{5}{*}{92} & \multirow{5}{*}{45} & \multirow{5}{*}{117} & 0.0 \\
\hline $43.3-62.4$ & Not good & 0 & & & & 0.0 \\
\hline $62.5-81.6$ & Enough & 27 & & & & 21.1 \\
\hline $81.7-100.8$ & Good & 70 & & & & 54.1 \\
\hline $100.9-120.0$ & Very good & 32 & & & & 24.8 \\
\hline TOTAL & & 130 & & & & 100 \\
\hline
\end{tabular}

From table 3, which came from 130 respondents from elementary school students in Batanghari, after being processed and the results obtained using the SPSS 21 application program, it was found that the students' wellness in thematic had a good category of $54.1 \%$ for 70 students from 130 total students, enough at $21.1 \%$ for a total of 27 students out of 130 total students, very good $24.8 \%$ for 32 students out of 130 total students. Of the 130 students having a Mean value of 92, a Maximum Value of 117, and a Minimum Grade of 45. 
Table 4. Student confidence in Batanghari elementary school

\begin{tabular}{|c|c|c|c|c|c|c|}
\hline \multicolumn{3}{|c|}{ Classification } & \multirow{2}{*}{ Mean } & \multirow{2}{*}{ Min } & \multirow{2}{*}{ Max } & \multirow{2}{*}{$\%$} \\
\hline Range & Attitude & Total & & & & \\
\hline $21.0-37.8$ & Not very good & 0 & \multirow{5}{*}{76} & \multirow{5}{*}{55} & \multirow{5}{*}{103} & 0.0 \\
\hline $37.9-54.6$ & Not good & 0 & & & & 0.0 \\
\hline $54.7-71.4$ & Enough & 21 & & & & 16.2 \\
\hline $71.5-88.2$ & Good & 74 & & & & 56.9 \\
\hline $88.3-105.0$ & Very good & 35 & & & & 26.9 \\
\hline TOTAL & & 130 & & & & 100 \\
\hline
\end{tabular}

Table 5. Relationship of attitude, independence, and confidence in elementary school students in Batanghari

\begin{tabular}{|c|c|c|c|c|}
\hline \multicolumn{2}{|c|}{} & Attitude & Self-Regulated & Self-confidence \\
\hline \multirow{3}{*}{ Attitude } & Pearson Correlation & 1 & $.718^{* *}$ & $.710^{* *}$ \\
\cline { 2 - 5 } & Sig. (2-tailed) & & .024 & .028 \\
\cline { 2 - 5 } & $\mathrm{N}$ & 130 & 130 & 130 \\
\hline \multirow{3}{*}{ Self-Regulated } & Pearson Correlation & $.718^{* *}$ & 1 & $.737^{* *}$ \\
\cline { 2 - 5 } & Sig. (2-tailed) & .024 & 130 & 130 \\
\cline { 2 - 5 } & $\mathrm{N}$ & 130 & $.737^{* *}$ & 1 \\
\hline \multirow{3}{*}{ Self-confidence } & Pearson Correlation & $.710^{* *}$ & .030 & 130 \\
\cline { 2 - 5 } & Sig. (2-tailed) & .028 & 130 & \\
\cline { 2 - 5 } & $\mathrm{N}$ & 130 & 130 \\
\hline
\end{tabular}

From table 4, which came from 130 respondents from elementary school students in Batanghari, after being processed and the results obtained using the SPSS 21 application program, it was found that the students' well-being in thematic categories was good at $56.9 \%$ for 74 students from 130 total students, enough at $16.2 \%$ for a total of 21 students out of 130 total students, very good $26.9 \%$ for 35 students out of 130 total students. Of the 130 students having a Mean value of 76, Maximum Value of 103, and Minimum Value of 55.

From table 5 we can see that the sig value is 0.024 smaller than 0.05 , it can be concluded that there is a relationship between independence and student attitudes in elementary schools in Batanghari with r-values of 0.518 and positive. If the sig value $<0.05$ then there is a relationship [28]. It can be seen that the sig value is 0.028 less than 0.05 , so it can be concluded that there is a relationship between students' attitudes and self-confidence in elementary schools in Batanghari. If the sig value $<0.05$ then there is a relationship [28].

\section{Discussion}

Based on the results obtained, it shows that more than half of respondents gave or showed a positive attitude in thematic learning. That is, if students show a positive attitude response it will improve learning outcomes better than other students. The low attitude in student learning can be overcome by including entertainment elements in the developed multimedia [29]; [30]. The attitude of students in learning cultural values is based on students' feelings or interests in learning, the learning [31]; [32]. In addition to feeling happy students can also emulate a cultural expert who is very expert in culture and find new things. Instead of assuming that culture is bad, dull, even there is no time for his family [33]; [34]. In addition, if students behave negatively toward cultural values, then these students have no interest in learning cultural values. Positive attitudes and interests in the subject of cultural values will lead to the future career of the student which will increase [35]; [36]. One that affects students in learning values is the lack of interest from students themselves. Therefore, to improve students in learning cultural values can use inquiry-based learning [37]; [38]; [39].

Learning independence in school is seen when students can express their opinions spontaneously when discussing in class and answering questions given by the teacher. This is in line with the opinion of [40], which states that student activity can be seen in their daily activities, for example he often read textbooks, seriously listens to teacher's information, often asks teachers, is active in class discussions, diligently practices in mastering skills and etc. The activity to look for references or learning resources that are less dominant due to the lack of internet access that is difficult to reach by students in the Batanghari sub-district and the only source of learning that is easily obtained is available books. This is in line with the opinion [41] that the independence of learning is a learning process where each individual can take the initiative, with or 
without the help of others, in terms of determining learning activities such as formulating learning goals, learning resources (either in the form of people or materials), diagnose learning needs and control the learning process yourself. In line with the opinion [26]; [42] students who have high learning independence will try to complete all the exercises or assignments given by the teacher with their own abilities. If students get into trouble then the student will ask questions or discuss with friends, teachers or other parties who are more competent in overcoming these difficulties.

One aspect of personality that shows quality human resources is one's level of self-confidence. Self-confidence has an important function to actualize one's potential. Many problems arise because a person lacks self-confidence, for example, a student who cheats on an exam is one example that the student does not believe in his own abilities, he relies more on others. This illustrates the unpreparedness especially of students in facing exams. Besides the low self-esteem that students have, encourages students to commit fraud in working on exam questions [43]. This is done because of the feelings of stress and anxiety experienced by students for fear of failing and not passing the national exam that has very strict assessment standards. A student who has confidence will try hard in conducting learning activities. Someone who has high confidence has a sense of optimism in achieving something as expected [44]. Conversely, someone who lacks confidence believes that he lacks the ability. Negative assessment of its ability can hamper efforts to be made to achieve the objectives to be achieved. These negative views and judgments cause students not to do any activities with all the capabilities they have [45]. Even though, it might actually have the ability.

From the results of the study in table 6 of the relationship between attitude and independence and self-confidence of students, it means that when students 'self-confidence and independence increase, students' attitudes toward thematic also increase. Students are more confident and independent when studying thematic. This causes the attitude towards learning is increasing [46]. From table 6 we can see that there is a strong relationship between attitude with student self-confidence, attitude with student independence and self-confidence in student independence, it does not rule out children who have good attitude lacking self-confidence or self-regulated. As a student in class has a good attitude in class, but when told to go forward to the class to answer the questions given, the student is not confident with himself and instead asks his friend to help answer the questions given.

\section{Conclusions}

Attitude is an important aspect of life in addition to cognitive and psychomotor, especially in education, by having a positive attitude, it will make someone better. This can be seen from the results of good categorized attitudes that will make students independent and confident in learning have good categories as well. Plus when an individual also has independence and good self-confidence in learning it will be able to influence the attitude of a person, this can be seen from the results of research that independence and attitude have a relationship of 0.718 and have a positive value and confidence and attitude to have a relationship amounted to 0.710 and has a positive relationship, which means that if the independence and confidence of students is good then the attitude of someone is good.

\section{Acknowledgements}

The researcher thanked the principal of the elementary school Batanghari which was the place of the study and became a sample of this research, I thank you, and all parties involved I thank you for that.

\section{REFERENCES}

[1] Astalini, A., Kurniawan, D. A. Sulistiyo, U., Perdana, R., \& Susbiyanto. (2019). E-Assessment Motivation in Physics Subjects for Senior High School. International Journal of Online and Biomedical Engineering (iJOE), 15(11), 4-15.

[2] Darmaji, D., Kurniawan, D. A., \& Irdianti. (2019). Physics education students' science process skills. International Journal of Evaluation and Research in Education (IJERE), 8(2), 293-298.

[3] Asrial., Syahrial., Kurniawan, D. A., Chan, F., Nugroho, P., Pratama, R. A., \& Septiasari, R. (2019). Identification: The Effect of Mathematical Competence on Pedagogic Competency of Prospective Teacher. Humanitiest \& Social Sciences Reviews (HSSR), 7(4), 85-92.

[4] Ornstein, A. C., \& Hunkins, F. P. (2009). Curriculum: Foundations, principles, and issues. Boston: Pearson.

[5] Min, K. C., Rashid, A. M., \& Nazri, M. I. (2012). Teachers' Understanding and Practice towards Thematic Approach in Teaching Integrated Living Skills (ILS) in Malaysia. Inernational Journal of Humanities and Social Science, 2(23), 273-281.

[6] Asrial., Syahrial., Kurniawan, D. A., Subandiyo, M., \& Amalina, N. (2019). Exploring obstacles in language learning among prospective primary school teacher. International Journal of Evaluation and Research in Education (IJERE), 8(2), 249-254.

[7] Kemdikbud. 2014. Materi Pelatihan Guru Implementasi Kurikulum 2013. Jakarta: Kemdikbud.

[8] Senyurut, S., \& Ozkan, Y, O. (2016). A Thematic and Methodological Analysis of Masters Dissertations in the Field of Measurement and Evaluation in Education. Elementary Education Online, 16(2), 628-653. 
[9] Kaya, H., \& Boyuk, U. (2011). Sikap terhadap pelajaran fisika dan eksperimen fisik siswa SMA. Jurnal Pendidikan Fisika Eropa , 2 (1), 23-31.

[10] Astalini., Kurniawan, D. A., Darmaji., Sholihah, L. R., \& Perdana, R. (2019). Characteristics of Students' Attitude to Physics in Muaro Jambi High School. Humanities \& Social Sciences Reviews (HSSR), 7(2), 91-99.

[11] Raved, L., \& Assaraf, O. B. Z. (2010). Attitudes towards Science Learning among 10th-Grade Students: A qualitative look. International Journal of Science Education, $1-25$.

[12] Liu, S., \& Laohawiriyanon, C. (2013). Students' Attitudes towards Cultural Learning in the English Classroom: A Case Study of Non-English Major Students in a Chinese University. International Journal of English Language Education. 1(3), 28-42

[13] Mantz Yorke (2014): The development and initial use of a survey of student 'belongingness', engagement and self-confidence in UK higher education, Assessment \& Evaluation in Higher Education, DOI: 10.1080/02602938.2 014.990415

[14] Yan, Z. (2019). Self-assessment in the process of self-regulated learning and its relationship with academic achievement, Assessment \& Evaluation in Higher Education, DOI: 10.1080/02602938.2019.1629390

[15] Zimmerman, B. J. 2000. "Attaining self-regulation: A social-cognitive perspective." In Handbook of Self-Regulation., edited by M. Boekaerts, P. Pintrich, and M. Zeidner, 13-39. San Diego, CA: Academic.

[16] Panadero, E. 2017. “A Review of Self-Regulated Learning: Six Models and Four Directions for Research." Frontiers in Psychology 8 (422): 1-28. doi:10.3389/fpsyg.2017.00422.

[17] Hawe, E., \& Dixon, H. (2016). Assessment for learning: a catalyst for student self-regulation, Assessment \& Evaluation in Higher Education. http://dx.doi.org/10.1080/ 02602938.2016 .1236360

[18] Zimmerman, B. J. 2008. "Goal Setting: A Key Proactive Source of Academic Self-Regulation." In Motivation and Self-Regulated Learning: Theory, Research and Applications, edited by D. H. Schunk and B. J. Zimmerman, 267-295. London: Lawrence Erlbaum.

[19] Clark, I. 2012. "Formative Assessment: Assessment is for Self-Regulated Learning." Educational Psychology Review 24 (2): 205-249. doi: 10.1007/s10648-011-9191-6

[20] Klenowski, V. 2009. "Assessment for Learning Revisited: An Asia-Pacific Perspective." Assessment in Education: Principles, Policy \& Practice 16 (3): 277-282. doi: 10.1080/09695940903319646..

[21] Panadero, E. 2017. “A Review of Self-Regulated Learning: Six Models and Four Directions for Research." Frontiers in Psychology 8 (422): 1-28. doi: 10.3389/fpsyg.2017.00422.

[22] Black, P. 2015. "Formative Assessment - An Optimistic but Incomplete Vision.” Assessment in Education: Principles, Policy and Practice 22 (1): 161-177. doi:10.1080/0969594 X.2014.999643.

[23] Kerlinger, F. N. (2014). Foundations of behavioral research. Yogyakarta: Gadjah Mada University Press.
[24] Cresswel, John W. (2012). Educational Research: Planning, Conducting, and Evaluating Quantitative and Qualitative Research. New York: Pearson

[25] Fraser, B. J. (1978). Development of a test of science related attitudes. Science Education, 62(4), 509-515.

[26] Ricky Lam (2014) Promoting self-regulated learning through portfolio assessment: testimony and recommendations, Assessment \& Evaluation in Higher Education, 39:6, 699-714, DOI: 10.1080/02602938.2013.8 62211

[27] Cohen, L., Manion, L., \& Morrison, K. (2007). Research Methods in Education: Routledge.

[28] Gall. D. M, et al. (2003). Education Research an introduction seventh edition. USA: Pearson Education. Inc

[29] Astalini, A., Darmaji, D., Kurniawan, W., Anwar, K., \& Kurniawan, D. A. (2019). Effectiveness of Using E-Module and E-Assessment. International Journal of Interactive Mobile Technologies, 13(9), 21-39.

[30] Astalini, A., Darmaji, D., Pathoni, H., Kurniawan, W., Jufrida., Kurniawan, D. A., \& Perdana, R. (2019). Motivation and Attitude of Students on Physics Subject in the Middle School in Indonesia. International Education Studies, 12(9), 15-26.

[31] Darmaji, D., Astalini, A., Kurniawan, D. A., Parasdila, H., Irdianti., Hadijah, S., \& Perdana, R. (2019). Practicum Guide: Basic Physics Based of Science Process Skill. Humanities \& Social Science Reviews (HSSR), 7(4), 151-160.

[32] Darmaji, D., Kurniawan, D. A., Astalini, A., Lumbantoruan, A., \& Samosir, S. C. (2019). Mobile Learning in Higher Education for the Industrial Revolution 4.0 Perception and Response of Physics Practicum. International Journal of Interactive Mobile Technologies, 13 (9), 4-20.

[33] Kurniawan, D, A., Astalini., \& Anggraini, L. (2018). Evaluasi Sikap SMP Terhadap IPA di Kabupaten Muaro Jambi. Jurnal Ilmiah Didaktika: Media Ilmiah Pendidikan dan Pengajaran. 19(1), 124-139.

[34] Astalini, A., Kurniawan, D. A., \& Anggraini, L. (2019). Correlation between with attitude toward science in secondary school in Indonesia. Beder Scientific Journal of Education Science (BJES), 20(1), 30-45.

[35] Asrial., Syahrial., Kurniawan, D. A., Chan, F., Septianingsih, R., Perdana, R. (2019). Multimedia Innovation 4.0 in Education: E-Modul Ethnoconstrucivism. Universal Journal of Educational Research. 7(10), 2098-2107.

[36] Maison., Astalini., Kurniawan, D. A., Perdana, R., Anggraini, L. (2019). The Phenomenon of Physicology Senior High School Education: Relationship of Students' Attitudes towards Physics, Learning Style, Motivation. Universal Journal of Educational Research. 7(10), 2199-2207.

[37] Astalini, A., Darmaji, D., Kurniawan, D. A., Melsayanti, R. (2019). E-Assessment of Student Perception of Natural Science Based on Seska in Middle School Students in Indonesia. International Journal of Scientific \& Technology Reseaerch, 8(9), 858-863.

[38] Kurniawan, D. A., Darmaji., Astalini., Sefiah, P. (2019). 
Description of Science Process Skills for Physics Teacher's Candidate. Azerbaijan Journal of Educational Studies. 684(3), 71-85.

[39] Astalini., Kurniawan, D. A., Perdana, R., Kurniawan, W. (2019). Identification Attitudes of Learners on Physics Subjects. Journal of Educational Science and Technology (EST), 5 (1), 39-48.

[40] Ziegler, N. A., and A. J. Moeller. 2012. "Increasing Self-regulated Learning through the Lingua Folio." Foreign Language Annals 45 (3): 330-348.

[41] Zimmerman, B., and D. H. Schunk, eds. 2001. Self-regulated Learning and Academic Achievement: Theoretical Perspectives. 2nd ed. Mahwah, NJ: Lawrence Erlbaum Associates.

[42] Lam, R. 2010. "The Role of Self-assessment in Student's Writing Portfolios: A Classroom Investigation." TESL Reporter 43 (2): 16-34.

[43] Hatice Sancar-Tokmak \& Tugba Yanpar-Yelken (2015): Effects of creating digital stories on foreign language education pre-service teachers' TPACK self-confidence, Educational Studies, DOI: 10.1080/03055698.2015.10439 78

[44] Heo, M. 2009. "Digital Storytelling: An Empirical Study of the Impact of Digital Storytelling on Pre-service Teachers' Self-efficacy and Dispositions towards Educational Technology." Journal of Educational Multimedia and Hypermedia 18 (4): 405-428.

[45] Sadler, I. (2013). The role of self-confidence in learning to teach in higher education, Innovations in Education and Teaching International, 50:2, 157-166, DOI: 10.1080/1470 3297.2012.760777

[46] Seba, J. M., Ndunguru, P. A., \& Mkoma, S. L. (2013). Secondary school students' attitudes towards Chemistry and Physics subjects in Tarime-Mara, Tanzania. TaJONAS: Tanzania Journal of Natural and Applied Sciences, 4(2), 642-647. 